Andrzej Sakowicz

University of Białystok

sakowicz@uwb.edu.pl

\title{
Commentary \\ on the Judgment of the Court of Justice of the European Union of 29 June 2016, case C-486/14, Criminal proceedings against Piotr Kossowski
}

The principle of ne bis in idem laid down in Article 54 of the Convention Implementing the Schengen Agreement read in the light of Article 50 of the Charter of Fundamental Rights of the European Union must be interpreted as meaning that a decision of the public prosecutor terminating criminal proceedings and finally closing the investigation procedure against a person, albeit with the possibility of its being reopened or annulled, without any penalties having been imposed, cannot be characterised as a final decision for the purposes of those articles when it is clear from the statement of reasons for that decision that the procedure was closed without a detailed investigation having been carried out; in that regard, the fact that neither the victim nor a potential witness was interviewed is an indication that no such investigation took place.

1. The judgment of the Court of Justice of the European Union (hereinafter: the Court) in the case C-486/14, criminal proceedings against Piotr Kossowski, is another opinion on final and binding discontinuation of criminal proceedings in the context of the principle of ne bis in idem applied in the European Union. The provision of Art. 54 of the Convention Implementing the Schengen Agreement (CISA) implies that the ne bis in idem principle protects an individual against a possible abuse of ius puniendi by a State and a possibility of charging him upon the same legal ground. It expresses not only a substantive and legal nature under the principle of nemo debet bis puniri (or ne bis poena in idem), that is a ban on subsequent punishment for the same act, but also assumes a barrier against reopening proceedings in the same 
case against the same defendant. Moreover, it allows to assume that on the basis of Art. 54 of the CISA, the principle of ne bis in idem is of a procedural nature being closely related to three values: freedom, security and justice, which are foundations of a uniform legal area. Insofar as the analyzed principle is connected with all of these values altogether, when considered separately, it depends on the location of axiological emphasis. The previous case law explicitly emphasized that ratio legis of Art. 54 of the CISA is "to assure that no one shall be prosecuted for the same acts in several Member States due to the exercise of the right of free movement"1. It can be easily noticed that the right of free movement will only be guaranteed when a person against whom criminal proceedings were terminated by a final judgment is granted a possibility of free movement within the Schengen area not fearing prosecution in another State for the same prohibited $\mathrm{act}^{2}$. Hence it may be said that Art. 54 of the CISA fulfils a function of a guarantee implementing the achievement of the above purpose. Yet it will only become possible if judgments of judicial authorities of other Member States are treated the same as one's own while the procedure connected with the recognition or enforcement of these decisions will be devoid of formalism ${ }^{3}$. Nevertheless, it cannot be unnoticed that in the more recent case law, the Court refers to legal security according to which the EU citizens are provided with the space of freedom, security and justice without internal borders where free movement of people is guaranteed in relation to appropriate measures with regard to control of external borders, asylum, immigration and counteracting and combating crime. Taking into account the normative content expressed in Art. 3 par. 3 of the TEU and Art. 67 par. 3 of the TFEU, the Court ruled in the case of Spasic that the principle of ne bis in idem enshrined in Art. 54 of the CISA "aims not only to avoid in the sphere of freedom, security and justice impunity of persons convicted in the EU by a final criminal judgment, but also guarantee legal security through the observance of judgments of public authorities which have become final in the context of a lack of harmonization or approximation of criminal law provisions of the Member States"4. It is apparently exemplified by a number of judgments of the Court on Art. 54 of the

1 The Judgment of ECJ 11 February 2003 Gözütok and Brügge, case C-187/01 and C-385/01, E.R.C. p. I-1345, para. 38.

2 See: the judgment of ECJ of 9 March 2006 Van Esbroeck, case C-436/04, para. 34; the judgment of ECJ of 28 September 2006, case Van Straaten, C-150/05, para. 46.

3 See: K. Ligeti: Rules on the Application of ne bis in idem in the EU. Is Further Legislative Action Required?, Eucrim 2009, No. 1-2, p. 38.

4 The Judgment of ECJ of 27 May 2014 Zoran Spasic, case C-129/14 PPU Criminal case agianst Zoran Spasic, para. 77; the Judgment of ECJ of 10 March 2005, case Miraglia, C-469/03 E.C.R. p. I-2009, para. 25; Compare: M. Wasmeier, Ne bis in idem and the Enforcement Condition, New Journal of European Criminal Law 2014, Vol. 5, Issue 4, p. 541-542. 
$\mathrm{CISA}^{5}$ concerning resolutions terminating criminal proceedings before referring the case to the court. Hence it should only be reminded that:

a) in the case of Miraglia the Court decided that a court judgment rendered without the resolution of the facts of the case does not terminate proceedings against a given person by the issue of a final judgment in the meaning of Art. 54 of the CISA, i.e. it does not exclude continuation of criminal proceedings in another Member State;

b) in the case of Gasparini and others, the Court emphasized that the principle of ne bis in idem applies to a judgment of Contracting Party passed in effect of criminal proceedings in result of which criminal proceedings against the defendant have been finally and bindingly discontinued due to the limitation of the offence under prosecution ${ }^{7}$;

c) in the case of Turanský, it has been pointed out that a decision on discontinuation of criminal proceedings rendered before the charges were brought against the suspect does not exclude initiation of new criminal proceedings for the same acts; a decision on suspension does not terminate proceedings by the issue of a final judgment justifying the application of the principle of ne bis in idem ${ }^{8}$, and

d) in the case of M., the Court decided that the interpretation of Art. 54 of the CISA should entail that a decision on discontinuation of investigation procedure and not referring the case to the court to decide about criminal liability (the decision which in the Contracting Party of its issue is an obstacle preventing repeated prosecution of a person against whom this decision has been issued for the same acts unless there is new evidence making the commission of the offence by this person more probable) should be recognized as a final and binding judgment in the meaning of this Article and effecting in an obstacle preventing repeated prosecution of the same person for the same acts in another Contracting Party ${ }^{9}$. Światłowskiej, Prawomocność orzeczenia jako element wyznaczający zakres zasady ne bis in idem w art. 54 Konwencji wykonawczej z Schengen, Europejski Przegląd Sądowy 2014, No. 5, p. 23-30; $\mathrm{Na}$ temat interpretacji pojęcia „prawomocny wyrok” zob. też B. Nita, Orzeczenia uruchomiające zakaz wynikający z zasady ne bis in idem w art. 54 Konwencji Wykonawczej z Schengen, Przegląd 
Each of the above judgments has been passed not only in distinct procedural systems but also different normative conditions of individual Member States. Nevertheless, a lack of normative solutions in some Member States or existing differences within their shape (e.g. related to a possibility of reopening proceedings terminated by a final judgment) cannot adversely affect the individual's legal situation. They cannot adversely affect the efficiency of measures preventing and combating crime as well. It has been confirmed by the Court in the case C-486/14, which added that the interpretation of validity in the meaning of Art. 54 of the CISA should be made "in the light of not only the need to assure free movement of people but also the need to support crime prevention and combating in the sphere of freedom, security and justice" 10 . Yet the point is that in the glossed judgment the Court has analyzed not the institution of domestic law in the context of establishment of validity of judgment used in Art. 54 of the CISA, but it assessed its nature in the context of hearing of evidence during the investigation procedure.

2. Critical comments to the thesis expressed in the introduction and the above presented reasoning of the Court should be preceded by a brief reference to the factual state which evoked a doubt embraced by the prejudicial question leading to the judgment rendered in the case C-486/14. The case started on 2 October 2005 when the Prosecution in Hamburg accused the suspect of committing acts qualified in the German law as extortion with aggravating factors, but the suspect fled from the territory of Germany. He was detained in Poland on 20 October 2005 during traffic control due to the final judgment sentencing him to deprivation of liberty still to be enforced. At the same time, Prosecution in Poland launched investigation procedure against the suspect for extortion with aggravating factors under Art. 282 of the Polish Criminal Code in connection with the acts committed by him in Hamburg on 2 October 2005. Although the relevant documents were handed over in the course of a legal aid, in December 2006 District Prosecution in Kołobrzeg delivered the Prosecution in Hamburg the decision of 22 December 2006 on discontinuation of criminal proceedings against the suspect due to a lack of sufficient grounds to suspect the offence has actually been committed. The decision was justified by the fact that the suspect refused to testify. Yet according to the hearsay, the victim in the main proceedings and the witness were residing in Germany and therefore they could not be interrogated during the investigation procedure. For this reason, the information given by the suspect - partially inaccurate and contradictory - could not be verified. At the same time the referring court added that according to the instructions on inherent measures of appeal attached to the decision terminating

Prawa Europejskiego i Międzynarodowego 2008, nr 1, p. 6 ff.; A. Sakowicz, Zasada ne bis in idem w prawie karnym, Białystok 2011, p. 361-406. 
criminal proceedings, the interested parties were entitled to appeal within seven days from the date of serving this decision. It should be emphasized that on 24 July 2009 the Prosecution in Hamburg issued a European Arrest Warrant for the suspect after obtaining a domestic decision on arresting the suspect on 9 January 2006 issued by the Amtsgericht Hamburg (a district court in Hamburg). However, the Regional Court in Koszalin refused to execute the European Arrest Warrant by the decision of 17 September 2009 due to the existence of the decision terminating criminal proceedings issued by the District Prosecution in Kołobrzeg, which was found final and binding by this court in the meaning of the Code of Criminal Procedure. Despite this, P. Kossowski, who was still wanted in Germany, was detained in Berlin on 7 February 2014, and in March 2014 the Prosecution in Hamburg brought an indictment against him. Landgericht Hamburg refused to launch court proceedings claiming that the prosecutor's right to prosecute expired in the meaning of Art. 54 of the CISA due to discontinuation of investigation procedure in the case for extortion with aggravating factors in Poland. In consequence thereof, this court annulled the arrest warrant for the suspect by the decision of 4 April 2014 while the suspect was released from custody, where he had been earlier remanded. The referring court, i.e. Hanseatisches Oberlandesgericht Hamburg, which the Prosecution in Hamburg appealed to against this decision, decided that in compliance with German law, a degree of suspicion of the commission of the act by the suspect is sufficient to justify a launch of court proceedings before Landgericht Hamburg and admit the indictment unless ne bis in idem principle expressed in Art. 54 of the CISA and Art. 50 of the CFR impedes this. Taking the above doubts into account, the referring court decided to raise a prejudicial question whether the objection submitted by Germany under Art. 55 par. 1 letter a of the CISA is still in force, or whether ne bis in idem principle contained in Art. 54 of the CISA and Art. 50 of the CFR should be interpreted in such a way that a suspect must not be chased in one Member State if criminal proceedings against this person initiated in another Member State have been discontinued by the Prosecution - without the execution of obligations imposed by the sanctions and without special investigation procedure - for factual reasons in effect of the lack of sufficiently justified suspicion of the commission of an act, and whether criminal proceedings may only be reopened if significant and earlier unknown circumstances have become known while yet such new circumstances do not occur in this case.

The Court of Justice decided that "a decision terminating criminal proceedings, such as the decision in issue before the referring court - which was adopted in a situation in which the prosecuting authority, without a more detailed investigation having been undertaken for the purpose of gathering and examining evidence, did not proceed with the prosecution solely because the accused had refused to give a statement and the victim and a hearsay witness were living in Germany, so that it had not been possible to interview them in the course of the investigation and had therefore not been possible to verify statements made by the victim - does not 
constitute a decision given after a determination has been made as to the merits of the case $^{\text {"11 }}$. The Court decided that the application of Art. 54 of the CISA to this type of a resolution would result in impediment, or would even be an obstacle for any specific possibility of punishment for unlawful conduct the suspect is accused of in interested Member States. On the one hand, the above mentioned decision on discontinuation of proceedings would be issued by judicial authorities of one Member State without any precise assessment of unlawful conduct the suspect is accused of. On the other hand, a launch of criminal proceedings for the same acts in another Member State would become problematic because this type of the effect would contradict the very purpose of Art. 3 par. 2 of the TEU mentioned above, the Court added.

3. The Court is right that the application of ne bis in idem principle in connection with the judgment issued in one Member State may result in the exclusion of prosecution in another Member State even if the courts of the second Member State could reach distinct conclusions on the basis of generally the same facts or evidence. It is indeed not surprising. It is a consequence of the failure to harmonize provisions within the area of criminal law, which should be remembered about when reaching conclusions ensuing from the analysis of individual judgments of the Court related to $n e$ bis in idem principle. In any case, as the Court rightly pointed out in earlier judgements: "nowhere in Title VI of the Treaty on European Union relating to police and judicial cooperation in criminal matters (Articles 34 and 31 of which were stated to be the legal basis for Articles 54 to 58 of the CISA), or in the Schengen Agreement or the CISA itself, is the application of Article 54 of the CISA made conditional upon harmonization, or at the least approximation, of the criminal laws of the Member States relating to procedures whereby further prosecution is barred"12.

Hence General Ombudsman Y. Bota rightly points out that ne bis in idem principle, which is now of a fundamental nature as a condition of the practical application of free movement, actually requires Member States to trust each other. Differences in domestic legislations cannot be an obstacle preventing observation of this principle. Even the Treaty on the Functioning of the EU itself expresses a legal base of approximation of legislations exclusively in order to facilitate the functioning of the mechanism of mutual recognition. Just by the application of the principle of mutual recognition, the EU legislator intended to overcome problems, seemingly insurmountable, due to the difficulties of a broader approximation of domestic legislations. The application of the principle of mutual recognition imposed on Member States the obligation of mutual trust regardless of the differences in their

11 Judgment of ECJ of 29 June 2016, case C-486/14, para. 48.

12 The judgment of ECJ of 11 February 2003 Gözütok i Brügge in joined cases C-187/01 and C-385/01, E.C.R. p. I-1345, para. 32; the judgment of ECJ of 9 March 2006 Van Esbroeck, C-436/04, E.C.R. p. I-2333, para. 29. 
respective domestic legislations, which is particularly apparent in the example of ne bis in idem principle included in Art. 54 of the CISA. This assumption is correct as it allows to implement guarantees resulting from ne bis in idem principle despite differences between legal systems of Member States, e.g. within the scope of understanding the notion of "a final judgment" ("prawomocny wyrok" in the Polish language version) occurring in other language versions as, e.g., rechtskräft ig Abgeurteilt in German, définitivement jugée in French, or bij onherroepelijk vonnis in Dutch. The subjective scope of these notions evokes numerous disputes in the doctrine, mostly ensuing from the attempted reading of the conventional notion by referring to domestic provisions ${ }^{13}$. Yet, as it was rightly indicated by the EU highest judicial instance in the joint cases of Gözütok and Brügge ${ }^{14}$, ne bis in idem principle "assumes that there is a necessary implication that the Member States have mutual trust in their criminal justice systems and that each of them recognizes the criminal law in force in the other Member States even when the outcome would be different if its own national law were applied" ${ }^{15}$. In other words, a possibility of a different resolution of a case results from a lack of harmonization.

This observation should be applied to judgments terminating proceedings during in personam stage by the Prosecutor's decision on discontinuation due to a lack of evidence. It must be clearly said - contrary to the Court's opinion - that validity of such a decision (if it is envisaged by domestic law) does not depend on the fact whether investigation procedure has been precisely carried out, or whether the victim or all witnesses have been interrogated. The adoption of the opinion expressed in the glossed judgment would mean that guarantees resulting from ne bis in idem principle would depend on the assessment of evidence heard during investigation procedure carried out by a body of another Member State. However, it is undeniable that such assessment contradicts mutual trust between Member States, challenges a sense of mutual recognition and opposes the idea of the area of freedom, security and justice. In this context, it should be held that recognition of judgments of judicial authorities of one Member State by the bodies of another Member State cannot depend on the fact that in one Member State the judgment is rendered during prosecutor's proceedings and in another - court proceedings. Due to a variety of legal systems of the EU Member States, ne bis in idem principle must be combined

13 Compare: R.M. Kniebühler, Transnationales “ne bis in idem", p. 176-190; A. Eicker, Transstaatliche Strafverfolgung. Ein Beitrag zur Europäisierung, Internationalisierung und Fortentwicklung des Grundsatzes ne bis in idem, St. Gallen-Harbolzheim 2004, p. 159-167; J.-F . Bohnert, O. Lagodny, Art. 54 SDÜ im Lichte der nationalen Wiederaufnahmegründe - Zugleich Besprechung von BGH, Urteil vom 10. 6. 1999 - 4 StR 87/98, Neue Zeitschrift für Strafrecht 2000, Heft 12, p. 638-639.

14 The judgment of ECJ of 11 February 2003 Gözütok $i$ Brügge (C-187/01 i C-385/01), E.C.R. p. I-1345, para. 33.

15 The judgment of ECJ of 11 February 2003 Gözütok $i$ Brügge (C-187/01 i C-385/01), E.C.R. p. I-1345. 
with the subject matter of a case and a perpetrator rather than the authority passing a judgment. The Supreme Court rightly noticed in the judgment of 2 June $2006^{16}$ that a Member State must recognize the results of criminal proceedings in other Member States even if they differ from the results of proceedings carried out on the basis of the State's own criminal law. It is obvious that legal systems may differ and possible attempts at overcoming this problem may be futile. Anyway, they cannot affect the implementation of ne bis in idem principle and respect of individual's rights. It should also be emphasized that trust means a specific presumption which allows to reach a specific procedural conclusion, or trust in decisions made by the system of justice officials, or, as preferred by others, a presumption that systems of justice in all Member States satisfy a minimum standard of human rights protection designated by the ECHR together with Protocols and dynamic Strasburg case law ${ }^{17}$. Lord Bingham in Dabas v. High Court of Justice in Madrid invoked the latter interpretation of the principle of mutual trust claiming that Member States share common values and recognize common rights; hence nothing impedes fairness of each other's judicial institutions ${ }^{18}$. Besides, trust may be based on mutual recognition of reconnaissance de plein droit, ipso iure, i.e. banning "evaluation" of the system of justice of the State in which judgment was given by the authorities of the State in which judgment was enforced to prove uselessness of exequatur procedure and reduce grounds for refusal to perform an action based on a specified instrument of cooperation in criminal cases. But to make it happen, mutual recognition should demonstrate mutual trust to legal systems and legal acts ${ }^{19}$, that is refer essentially to the Anglo-Saxon comity and

16 The judgment of the Supreme Court of 2 June 2006, IV KO 22/05, OSNKW 2006, No. 7-8, item 75.

17 See: G de Kerchove, A. Weyembergh (eds): La confi ance mutuelle dans l'espace penal européen/ Mutual Trust in the European Criminal Area, Editions de L'Universite de Bruxelles, Bruxelles 2005, passim; S. Peers: Mutual recognition and criminal law in the European Union: Has the Council got it wrong?', 41 CMLR 2004, Vol. 41, p. 5; V. Mitsilegas: The constitutional implications of mutual recognition in criminal matters in the EU, CMLR 2006, Vol. 43, p. 1277; M. Fichera, Ch. Janssens: Mutual recognition of judicial decisions in criminal matters and the role of the national judge, „ERA Forum” 2007, vol. 8, p. 177.

18 See the Judgment of the Court of Appeal of England and Wales, Dabas v. High, Court of Justice in Madrid of 28 February 2007, [2007] UKHL 6; AC 31, para 4 - „The important underlying assumption of the Framework Decision is that member states, sharing common values and recognising common rights, can and should trust the integrity and fairness of each other's judicial institutions". In other judgment King's Prosecutor (Brussels) v Cando Armas, [2005] UKHL 67; [2006] 2 A.C. 1 para. 2] „movement among the member states of the European Union.. to establish, as between themselves, a simpler, quicker, more effective procedure, founded on member states' confidence in the integrity of each other's legal and judicial systems".

19 It is aptly pointed out in German literature that the trust in foreign laws and their lawful application, constituting the dogmatic basis of the principle of mutual recognition, allows its application also in criminal cases, compare N. Kotzurek, Gegenseitige Anerkennung und Schutgarantien bei der Europäischen Beweisanordnung, ZIS 2006, p. 126; A. Sakowicz, Zasada ne bis in idem w prawie karnym, Białystok 2011, p. 206-207 and the literature given there. 
extradition principle of non-inquiry according to which a court of the requested State may not examine the process of the issue of a request for extradition ${ }^{20}$.

4. In the glossed judgment and reasons thereto, the Court omitted opinions which had appeared in earlier rulings. Both those underling that ne bis in idem principle "does not fall to be applied in respect of a decision of the judicial authorities of one Member State declaring a case to be closed, after the Public Prosecutor has decided not to pursue the prosecution on the sole ground that criminal proceedings have been started in another Member State against the same defendant and for the same act"21, and those saying that "Article 54 of the CISA must be interpreted as meaning that an order making a finding that there is no ground to refer a case to a trial court which precludes, in the Contracting State in which that finding was made, the bringing of new criminal proceedings in respect of the same acts against the person to whom that finding applies must be considered to be a final judgment, for the purposes of that article, precluding new proceedings against the same person in respect of the same acts in another Contracting State" 22 .

What is more, the Court failed to notice that a decision on discontinuation of investigation procedure due to a lack of sufficient evidence in the in personam stage may be issued by different authorities having or failing to have the force of res judicata. It is enough to consider here, e.g., the decision of a judge in charge of preliminary enquiries on discontinuation of proceedings due to a lack of evidence ("ordonnance de non-lieu par des raisons de fait" - Art. 177 of the French Code of Criminal Procedure) which does not have a feature of res judicata ${ }^{23}$. Doubts also arise with regard to different decisions on discontinuation of investigation procedure in Germany (in particular if we analyze the decision issued under $\$ 204$ par. 1 of the German StPO called Nichteröff nungsbeschluss) ${ }^{24}$. It is similar to the Belgian

20 M. Cherif Bassiouni, International Extradition: United States: Law and Practice, Nowy Jork 2002, p. 572.

21 Judgment of ECJ of 10 March 2005 in case Filomeno Mario Miraglia, (C-469/03), Judgment of ECJ of 28 September 2006 in case Van Straaten, C-150/05), para. 60; see more: B. Nita, Artykuł 54 konwencji wykonawczej z Schengen w wyrokach Europejskiego Trybunału Sprawiedliwości z 28 września 2006 r., C-467/04, postępowanie karne przeciwko Giuseppe Francesco Gasparini i innym oraz C-150/05, Jean Leon Van Straaten przeciwko Niderlandom i Republice Włoskiej, „Europejski Przegląd Sądowy” 2007, No. 9, p. 4452; A. Sakowicz, Zasada ne bis in idem w prawie karnym, Białystok 2011, p. $384 \mathrm{ff}$.

22 Judgment of ECJ of 5 June 2014, case C-398/12 M., E.R.C. p. I-1057.

23 F.-F. Bohnert, O. Lagodny, Art. 54 SDÜ im Lichte der nationalen Wiederaufnahmegründe - Zugleich Besprechung von BGH, Urteil vom 10. 6. 1999 - 4 StR 87/98, Neue Zeitschrift für Strafrecht 2000, Heft 12, p. 638-639.

24 Por. R.M. Kniebühler, Transnationales „ne bis in idem”, p. 238-244; G. Dannecker, Die Garantie des Grundsatzes „ne bis in idem” in Europa, (in:) H.J. Hirsch, J. Wolter, U. Brauns (Hrsg.), Festschrift für Günter Kohlmann zum 70. Geburtstag, Kolonia 2003, p. 608 ff., B. NitaŚwiatłowska, Prawomocność orzeczenia jako element wyznaczający zakres zasady ne bis in idem 
decision on arrêt de de non lieu par des raisons de fait (Art. 128 of the Belgian CCP), which stipulates that investigation procedure shall be discontinued if in effect of the referral of a case to the first instance court which supervises investigation procedure carried out by a judge, it turns out that the act is neither a crime nor misdemeanour or offence, or there is no evidence implying the commission of an offence. With respect to the Belgian decision, in the case of $\mathrm{M}$. the Court rightly decided that such a decision had been issued as to the essence of the case and is of a final nature because it entails "the expiry of possibilities of bringing the indictment by a public prosecutor at national level" and activates a ban on a repeated pursuit of criminal proceedings against the same perpetrator for the same prohibited act. Expressing this opinion, the Court was aware of legal regulations being in force in the Belgian system which allow to reopen a decision of arrêt de de non lieu par des raisons de fait if new evidence implying the commission of an offence emerge (Art. 246-248 of the Belgian $\mathrm{CCP}$ ). The Court clearly underlined in this case that "the possibility of reopening the criminal investigation if new facts and/or evidence become available, as provided for in Articles 246 to 248 of the CIC, cannot affect the final nature of the order making a finding of 'non-lieu' at issue in the main proceedings. While that possibility is not an 'extraordinary remedy', within the meaning of the case-law of the European Court of Human Rights just cited, it does involve the exceptional bringing of separate proceedings based on different evidence, rather than the mere continuation of proceedings which have already been closed. Furthermore, in view of the need to verify that the evidence relied on to justify the reopening of the proceedings is indeed new, any new proceedings, based on such a possibility of reopening, against the same person for the same acts can be brought only in the Contracting State in which that

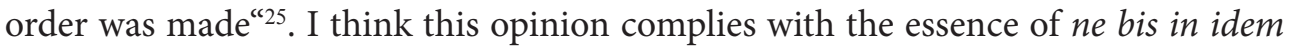
principle and mechanisms of cooperation in criminal cases within the EU. Therefore the interpretation of Art. 54 of the Schengen Agreement should be made within the subject and purpose of this provision while intending to assure a proper effect of ne bis in idem principle, and not interpreting formal procedural provisions of Member States, whose nature is not uniform if we take individual legal systems into consideration.

Summing up, it should be indicated that a similar doubt arises on the basis of the Polish CCP, i.e. when a decision on refusal to initiate or discontinue proceedings due to a lack of sufficient grounds to suspect the act has been committed is issued (Art. $17 \$ 1$ point 1 of the CCP). Nevertheless, it should be noticed that such a decision becomes substantively valid when the time limit to challenge it has effectively lapsed or, relatively, if the course of instance control has been exhausted. A possibility of

w art. 54 Konwencji wykonawczej z Schengen, „Europejski Przegląd Sądowy” 2014, No. 5, p. 28 29; A. Sakowicz, Zasada ne bis in idem w prawie karnym, Białystok 2011, p. $384 \mathrm{ff}$. 
the decision's withdrawal under extraordinary circumstances, i.e. after fulfilling prerequisites indicated in Art. $327 \$ 2$ of the CCP, does not annul the force of legal validity because it is an exceptional situation. Moreover, exceptionality of this situation is different depending on who made a decision on discontinuation of investigation procedure due to a lack of evidence - a prosecutor or court before opening proceedings (Art. $339 \$ 3$ point 2 of the CCP). In the first situation, new significant facts or evidence previously unknown may be the grounds for further continuation of investigation procedure while legally valid discontinuation of proceedings by the court may not cause reinstitution of criminal proceedings against the defendant. This difference, resulting from our legal system, may neither limit the operation of ne bis in idem principle within Member States nor secure certainty of an individual's legal situation distinctly because both these decisions are legally valid and final and issued as to the essence of the case ${ }^{26}$. It is also known, since the judgment in joint cases of Gözütok and Brügge, that ne bis in idem principle expressed in Art. 54 of the CISA is also applicable to prosecutor's proceedings undertaken without the participation of a court and it definitely terminates criminal proceedings; thus the form of a decision and its source from a specific procedural authority do not conclusively matter within the scope of the analyzed principle ${ }^{27}$.

26 Differently M. Wąsek-Wiaderek, Prawomocne umorzenie postępowania przygotowawczego jako rozstrzygnięcie kreujące zakaz ne bis in idem w Unii Europejskiej, (in:) M. Sitarz, P. Stanisz, H. Stawniak (eds.), Reddite ergo quae sunt Caesaris Caesari et quae sunt Dei Deo. Studia in honorem Prof. Josephi Krukowski Dedicata, Lublin 2014, p. 908-909.

27 B. Nita-Światłowska, Prawomocność orzeczenia jako element wyznaczający zakres zasady ne bis in idem w art. 54 Konwencji wykonawczej z Schengen, „Europejski Przegląd Sądowy” 2014, No. 5, p. 30 . 